\title{
Nicolas Bourriaud, Estetyka relacyjna, przeł. Łukasz Białkowski, Muzeum Sztuki Współczesnej MOCAK, Kraków 2012, s. 150
}

DOI: http://dx.doi.org/10.12775/RF.2014.024

Pojawienie się na rynku polskim jednej z najciekawszych książek, poruszającej zagadnienia sztuki współczesnej pt. Estetyka relacyjna, autorstwa Nicolasa Bourriaud, zawdzięczamy działalności wydawniczej Muzeum Sztuki Współczesnej w Krakowie (MOCAK). Wydana w 2012 roku pozycja wypełnia istotną lukę dotyczącą publikacji na temat lat dziewięćdziesiątych, będąc nie tylko opisem ówczesnych wydarzeń, lecz przede wszystkim ich teoretyczną interpretacją, opartą na wielu odniesieniach filozoficznych.

Dyskusje wokół myśli o sztuce, zawarte w omawianej tu książce, toczyły się nie tylko w wiodących ośrodkach artystycznych i naukowych, lecz także w Skandynawii, Meksyku czy Tajlandii. Często wzbudzała ona skrajne reakcje środowiska, stając się tematem polemik prowadzonych na stronach magazynów artystycznych m.in. "Artforum” oraz „October". Zamieszanie wokół tej publikacji stanowiło, zdaniem autora, wręcz utrudnienie dla przeciętnego czytelnika, który skazany był bardziej na uprzedzenia i narosłe nieporozumienia niż na czysty odbiór. Tymczasem, książka - choć różnie oceniana - nosi w sobie odzwierciedlenie wszechstronnych kompetencji autora. Bourriaud mówi w niej zarówno jako krytyk, teoretyk sztuki, jak i kurator. Pomimo, że powstawała fragmentami, przedstawia całościową koncepcję interpretacyjną w oparciu o podstawowe wartości pokolenia. Były nimi głównie tzw. praktyki relacyjne, których znaczenie, mimo powszechności zastosowań, wcale nie wydawało się oczywiste. Stąd przede wszystkim wynikała kontrowersyjność tej publikacji, której początkowo zupełnie nie przyznawano prawa do bycia głosem na nowo definiującym sztukę. Współczesny odbiorca, posiadający pewien dystans do opisywanych czasów, z pewnością łatwiej dziś dostrzeże jej rolę i atrakcyjność.

Główną myślą którą autor dzieli się już we wprowadzeniu, można w skrócie ująć następującymi słowami: „To, czego nie da się skomercja- 
lizować, musi zniknąć". Nie jest to bynajmniej manifest jego propozycji intelektualnej, co raczej diagnoza sytuacji, z której wyjścia szuka. Jeśli, jak pisze, stosunki międzyludzkie zostały zreifikowane, sprowadzane do przedmiotu handlu przy kawie „w rozsądnej cenie” , to sprawą sztuki jest - choćby narażając się na zarzut tworzenia utopii - próbować podejmować problemy, które wskażą alternatywną rzeczywistość. W oparciu o dokonania artystów oraz myśl filozoficzna, Bourriaud buduje szczegółową koncepcję, na nowo definiując wiele pojęć. Imponująca jest jego warsztatowa dokładność, dzięki której możemy (a wręcz powinniśmy) obcować z książka, mając pod ręką umieszczony na końcu słownik. Ujednoznaczni on to, co autor miał na myśli, posługując się podstawowymi dla teorii sztuki terminami: artysta, estetyka, forma, obraz, styl, sztuka, lecz także tymi bardziej charakterystycznymi już dla jego koncepcji, jak: kryterium współistnienia, relacyjne sztuka i estetyka, realizm operacyjny, społeczeństwo figurantów. W większości są one dobrze znane, lecz często przybierają w ramach estetyki relacyjnej szczególną postać.

Francuski krytyk sugeruje, aby rozpocząć lekturę od pojęcia fundamentalnego tj. sztuki. Jak ją rozumie? Przytoczmy najważniejszy fragment zasugerowanej już definicji: „sztuka to aktywność polegająca na wytwarzaniu relacji ze światem za pomocą znaków, form, gestów lub przedmiotów"1. ${ }^{\prime \prime}$ Z klasycznej opowieści, jaką była w ramach tradycyjnej historii sztuki, pozostała już, według autora, jedynie pozostałość semantyczna. Dlatego to, na czym się skoncentruje w swojej książce, to odtwarzanie i budowanie projektu kluczowej, tytułowej relacji. Bourriaud sięga w tym celu głęboko. Po pierwsze, pojawiają się odniesienia do szeroko pojętej dialogiczności w filozofii: Lévinasa, marksizmu, lecz także, co z perspektywy polskiego czytelnika szczególnie ciekawe, Gombrowicza. Po drugie, do myśli postmodernistycznej, zwłaszcza reprezentowanej przez Lyotarda. Wobec tej autor omawianej książki wyraźnie się dystansuje, szukając dla siebie drogi rozwoju w opozycji do słabości, jakie postrzega w koncepcjach epoki „post-”. Pod tym hasłem kryje się zresztą nie tylko, jak można by się domyślać, postmodernizm. Także to, co postkolonialne, postfeministyczne, postludzkie, posthistoryczne itp. itd. Łatwo wobec tego wywnioskować, że lokująca się poza wymienionymi - jak sam Bourriaud je określa - mitami końca XX wieku koncepcja skazuje się na bycie na obrzeżach. W niczym jej to jednak nie deprecjonuje. Pozwala raczej na pewną oryginalność myśli oraz aktualność. Nie pozostaje ona bowiem obojętna także wobec innych zjawisk charakterystycznych dla naszej epoki. Wymieńmy je za autorem Estetyki

1 N. Bourriaud, Estetyka relacyjna, przeł. Ł. Białkowski, Muzeum Sztuki Współczesnej MOCAK, Kraków 2012, s. 150. 
relacyjnej: globalizacja, imigracja, niewidzialność władzy i kapitału, sterowane wyzbywanie się ludności tożsamości kulturowej.

Budzący się głos sztuki, która ma zająć własne stanowisko w stosunku do nich, posługuje się terminem „wędrujący” (radicant). Co on oznacza? Francuski krytyk odwołuje się do znaczenia botanicznego i przyjmuje na swoje potrzeby obraz wędrującego korzenia, na którego podobieństwo myśl ma wrastać w to, co trwałe. Posługując się tą metafora, kreśli przed nami wizję, która określa zadanie estetyki relacyjnej jako tej, która wnika w ustalone tożsamości, przepracowuje przeszłość, a także wyróżnia model włóczęgi jako adekwatny dla współczesnych praktyk artystycznych ${ }^{2}$. Przypatrzmy się przez moment, jak Bourriaud opisuje te ostatnie. Będąc świadom ruchów, jakim podlegają autor stara się wywieść ich aktualne posłannictwo i sens. Okazuje się to zadaniem niełatwym, ponieważ mamy do czynienia z okresem, w którym idealistyczna i teleologiczna wersja nowoczesności umarła. To, co w powszechnym mniemaniu pozostało artystom, można zilustrować słowami Lyotarda, którymi określał on architekturę. Tak jak ona, tak i cała dzisiejsza sztuka wydaje się skazana na „tworzenie serii drobnych modyfikacji w przestrzeni odziedziczonej po nowoczesności i na wyrzeczenie się globalnej rekonstrukcji przestrzeni zamieszkiwanej przez człowieka"3. Czy jednak rzeczywiście nie ma wyjścia z tej sytuacji? Estetyka relacyjna w kryzysie dostrzega możliwość przemiany. Głosi, że zamiast utraconej szansy konstruowania, którą opłakujemy, trzeba zwrócić się ku szansie historycznej, na którą taki stan nas otwiera. Jest nią zadanie, aby „nauczyć się lepszego gospodarowania światem”" . Gospodarowanie, zamiast konstruowania, staje się na kartkach tej książki podstawowym zadaniem sztuki współczesnej. Jest to wręcz nowa utopia naszych czasów.

Stąd sympatia i uwaga krytyka skupia się przede wszystkim na działaniach lokalnych artystów. Autor wspomina swoje doświadczenia, kiedy jako zaangażowany obserwator przyglądał się pracy grup, dla których priorytetem było wkraczanie ze swoją aktywnością twórczą w sferę relacji międzyludzkich. Ich działalność, opierająca się także na wspólnych dyskusjach i przyjaźniach, zainicjowała bezpośrednio powstanie omawianej książki. Autor wymienia wiele nazwisk ${ }^{5}$, podkreśla-

2 Metaforze tej towarzyszą konkretne zadania i założenia metafizyczne, zwłaszcza dotyczące czasu. Bourriaud mówi o tzw. heterochronii, tj. trwaniu, gdzie czas zmierza w stronę od przyszłości do przeszłości. Stąd znacząca rola przeszłości, która dla współczesnych artystów pełni podobną rolę, jaką niegdyś przypisywano przyszłości.

3 N. Bourriaud, Estetyka relacyjna, s. 41.

4 Ibidem.

5 Wszyscy artyści, których Bourriaud wymienia, wzięli udział w zorganizowanej przez niego wystawie „Traffic” w styczniu 1996 roku. 
jąc, że pomimo różnic między artystami, wspólne im było to, że prace, które stworzyli, można było odczytać przez pryzmat analizy stosunków międzyludzkich. Oczywiście takie łączące się z tym typem działalności zjawiska, jak: interaktywność, kontekst społeczny czy uczestnictwo, istniały już wcześniej, jednak, jak się podkreśla, na potrzeby działań w latach dziewięćdziesiątych zostały one przepracowane na nowo, pozwalając artystom ponownie zinterpretować świat i wkroczyć w niego ze swoimi działaniami.

Zwróćmy się więc już bezpośrednio ku teorii. Jaki przybrała kształt? Kilka cech dla niej charakterystycznych zostało już wymienionych. Pozostałymi, specyficznymi dla niej pojęciami są np. "forma relacyjna", "dzieło sztuki jako szczelina" czy "forma jako trwałe spotkanie" - terminy rozwijające różnorodne oblicza relacji. Francuski krytyk ugruntowuje opracowywane przez siebie pojęcia na solidnych podstawach filozoficznych. Punktem wyjścia jest dla niego materializm w kształcie, jaki nadał mu Althusser, tzw. ",materializm spotkania” lub materializm aleatoryczny. Zakłada on przypadkowość świata. Nie poprzedza go żaden sens, nie zmierza do żadnego celu, wyznaczanego przez Rozum. W takim świecie jednostka powstaje ze związków, które łączą ją i innych w historyczne formy społeczne. Z tych dwu założeń wynika to, że estetyka relacyjna nie może być pojmowana jako klasyczna historia sztuki (ta, jak pisze Bourriaud, zwykła zakładać źródła i cele), co sprawia, że omijają ją takie katastrofy, jak „koniec sztuki” czy „koniec historii”. Jej status odzwierciedla dalej tocząca się gra, o której kształcie decydują kontekst, gracze oraz ich krytyka systemu.

Dynamika decyduje nie tylko o kształcie gry. Także sama forma bywa chwiejna i wieloznaczna. Napotykamy tu inspirujące porównanie, sięgające źródeł myśli, tj. koncepcji atomów. Tak jak one, w teorii Epikura i Lukrecjusza, mogą zboczyć z kursu, napotkać atom sąsiedni i spowodować kataklizm albo narodziny, tak z pewnych odchyleń i spotkań powstają formy. Dzięki temu definiuje się dzieło sztuki, które przybiera podobny kształt - spotykają się w nim elementy, które dotąd były oddzielone: linie i kolory. Łącząc się trwale, inicjują powstanie nowych możliwości istnienia. Każde dzieło staje się zatem „modelem żyjącego świata" ${ }^{\prime \prime}$. Aby wyjaśnić głębiej to na nowo zdefiniowane pojęcie, Bourriaud odwołuje się także do koncepcji formy z powieści Gombrowicza. Przywołuje elementy koncepcji tego polskiego pisarza, w której zakłada on, że to, kim jesteśmy, to wynik naszych ciągłych relacji z innymi. Przez analogię określa dzieło, o którego kształcie decydują również relacje międzyludzkie - w postaci starć, dyskusji na jego temat.

Tak dochodzi do kolejnego spotkania między obrazem a widzem. Wyraża się ono w zachodzącej możliwości wypracowywania znaczenia.

${ }^{6}$ N. Bourriaud, Estetyka relacyjna, s. 48. 
Ujmuje się je tu w kategoriach „więzów”, zacieśnienia relacji. Przebywanie we wspólnej przestrzeni wraz z dziełami sztuki, np. podczas wystawy, komentowanie i dyskutowanie wzmaga taki stan. Jest to jednak jedynie „szczelina”. Zaczerpnięty od Marksa termin miał początkowo określać zachowania rynkowe nienastawione na zysk, które wymykają się zasadom ekonomii kapitalistycznej. Użyty w omawianej teorii, odzwierciedla naturę sztuki, która na tle powszechnych zachowań, jest jednak wciąż mało popularna.

Pożądane "uczestnictwo" widza z filozoficznego terminu stało się rzeczywistym elementem praktyki artystycznej. Główną rolę w podjęciu refleksji nad nim odegrały w świecie sztuki oczywiście happeningi, a także prace Duchampa, które starały się określić zakres interwencji widza w dzieło sztuki. Mamy więc do czynienia z procesem, który powodował stopniowy wzrost interaktywności. Także nowe technologie mogą być rozumiane jako odzwierciedlające potrzebę ludzkości stworzenia nowych typów związków i przestrzeni wspólnotowości ${ }^{7}$. Oparta na doświadczeniu lat dziewięćdziesiątych propozycja estetyki relacyjnej, świadoma tej ewolucji, podaje nawet pomysł napisania całej, nowej historii sztuki, która spróbowałaby ująć swoje dzieje właśnie pod kątem relacji zainicjowanych przez dzieła ze światem zewnętrznym. W jednym z rozdziałów przedstawianej pracy, przybliża się nam pokrótce ich genezę, poprzez początkowe skierowanie w stronę sacrum, ku człowiekowi. Dziś, i jest to, zdaniem tego krytyka, znak czasów, jesteśmy świadkami nastania nowego etapu w eksplorowaniu pojęcia. Objawia się ono, jak wspomnieliśmy, przede wszystkim w zainteresowaniu stosunkami międzyludzkimi. Dzięki temu różnorodne sposoby spotykania się i wytwarzania relacji, jak np.: mityngi, manifestacje, różne formy współpracy, gry, festyny stały się estetycznymi obiektami.

Choć potencjał teoretyczny „estetyki relacyjnej” nie wydawał się od początku oczywisty, a artystów podzielających wspomniane wartości długo nie uznawano za wiodący głos pokolenia, perspektywa czasu podkreśla wagę ich dokonań. Przetłumaczenie i wydanie książki w Polsce w XXI wieku także nie jest pozbawione aktualności. Wydaje się ono pozostawać w zgodzie z licznymi projektami artystycznymi, które wpisują się nie tylko w profil działań macierzystej instytucji jej wydawcy, lecz także innych miejsc w całym kraju.

Malina Barcikowska

7 Szerzej zagadnienie to porusza np. Ryszard W. Kluszczyński w swojej książce Sztuka interaktywna. Od dzieła-instrumentu do interaktywnego spektaklu, Wydawnictwa Akademickie i Profesjonalne, Warszawa 2010. 